\title{
Determination of the Structure and Composition of the 'Sulphur Granules' of Actinomyces bovis
}

\author{
BY L. PINE \\ Department of Microbiology, Duke University Medical Centre, Durham, \\ North Carolina \\ AND J. R. OVERMAN \\ Department of Microbiology and Department of Medicine, Duke University \\ Medical Centre, Durham, North Carolina, U.S.A.
}

(Received 27 December 1962)

\begin{abstract}
SUMMARY
'Sulphur granules' of Actinomyces bovis were isolated from a case of bovine actinomycosis. These were examined in ultrathin sections with the electron microscope, in stained sections with the light microscope or in wet mounts before and after chemical extraction with the light and phase microscope. In addition chemical analyses were done on the granules and on organisms grown in vitro. The combined results showed the granule is a mycelial mass of Actinomyces bovis cemented together by a polysaccharide+ protein complex and containing about $50 \%$ calcium phosphate. With the exception of the calcium phosphate, the granule had essentially the same composition as organisms grown in vitro. It is concluded that the 'clubs' of the granule represent normal hyphae encapsulated with the same polysaccharide + protein complex, that the basic structure of the granule represents the organism itself or products formed by it and that the mycelial mass is mineralized by calcium phosphate derived from the host as a result of phosphatase activity of the host and organism.
\end{abstract}

\section{INTRODUCTION}

Cohn (1875) first described the microscopic appearance of a strain of Actinomyces in stained preparations. The source of the material was concrements taken from the lacrimal canal of an infected eye. Although these preparations showed the presence of a small branching organism or mycelial masses, it was not until Harz described the organism (Bollinger, 1877; Harz, 1879) in actinomycosis of cows that attention was focused on the very hard grain-like structures formed by the organisms in animals. These structures, because of their colour and consistency, became known as 'sulphur granules'. With the discovery of the disease and its description in man by Israel (1878) and Ponfick (1880) it was soon recognized that the granules were invariably present in the diseased tissue and could be observed and easily isolated from the draining sinuses caused by the infection. Consequently, their presence was soon regarded as a laboratory aid in the diagnosis of the disease. The granule formed by Actinomyces in invasive infections had characteristics which made it readily identifiable. It was hard, gritty, and generally contained a rosette of 'clubs' at its surface. When a crushed granule was stained by the Gram reaction, 
a Gram-positive filament was often observed within a club which was, itself, Gram negative. Because of its relationship to the disease and because of the importance of the disease at the time, there was considerable speculation in regard to the structure and composition of the granule and the clubs surrounding it. Knaysi (1951) described the club as a filament of the fungus having a capsule and stated that the club or portion surrounding the mycelial element could not be construed as a part of the organism proper. Emmons (1935) proposed that the club was a result of the host cells depositing on the surface of the filament. Cromartie, Spitznagel \& Crawford (1960) showed that an accumulation of a basic protein of high arginine content occurred at the periphery of the sulphur granules but that the protein appeared to be in and around the radially arranged clubs. In an infection of the lacrimal canal in which the organism appeared to be non-invasive the mycelial mass observed was granular in form but was relatively soft and contained no clubs (Pine, Shearin \& Gonzales, 1961). Only once have typical sulphur granules been observed to form in vitro (Wright, 1905).

To the student of actinomycosis, the question still remains 'What is the sulphur granule?'. Pine \& Watson (1959) and Pine, Howell \& Watson (1960) described four cases of bovine lumpy jaw and the organisms which caused the infections. Of these cases, three provided large amounts of pus containing the granules which were subsequently frozen for class use. With this material an investigation was undertaken to answer the above question by using the techniques of electron microscopy, classical histochemical examination, and phase microscopy, together with comparative chemical analyses of the in vitro-grown isolate and the granules which it formed in the cow. The results show that the sulphur granule is a mycelial mass cemented together by a polysaccharide+ protein complex excreted by the organism as a capsule. This material and the mycelial mass in the centre are mineralized with calcium phosphate.

\section{METHODS}

\section{Bacteriological methods}

Three cow heads with lumpy jaw (cases P 1, P2, P3; Pine \& Watson, 1959) were the source of the material used. The large interlocking sinuses were reamed with a semiconical spatula and the total material obtained from each case was frozen in vials and stored separately. In the period of three years all of the vials were subjected several times to thawing so that samples could be withdrawn. It is recognized that such a treatment probably changed the intracellular structures, but the experiments reported here indicate that no major changes occurred which would have altered the basic granule structure. A single direct comparative experiment with Actinomyces $\mathrm{P} 2 \mathrm{~s}$ grown in vitro (Pine et al. 1960) frozen once and then thawed, showed no alteration of cellular structures as observed in ultrathin sections examined with the electron microscope.

The culture of Actinomyces bovis $\mathrm{P} 2 \mathrm{~s}$ used for cell-wall analyses was grown in the Casitone medium of Pine \& Watson (1959) under an anaerobic seal and supplemented with $\mathrm{NaHCO}_{3}$ during growth (Buchanan, 1962). The culture was grown in a 12 l. Florence flask for 7 days at $37^{\circ}$. The organisms were centrifuged down, washed 3 times with distilled water and dried over $\mathrm{P}_{2} \mathrm{O}_{5}$ in a vacuum desiccator. 
Other cultures of Actinomyces P2s were grown in $5 \mathrm{ml}$. lots of the same medium for 3-4 days at $37^{\circ}$, the pyrogallol + sodium carbonate seal serving as the source of carbon dioxide.

\section{Electron microscope procedures}

Comparative experiments with trypsin or $10 \% \mathrm{KOH}$ showed that treatment of the granules with KOH was superior for the removal of the pus and debris surrounding the granule and did not appear to alter the granule itself. Consequently, the granules and pus of case $\mathrm{P} 2$ were suspended in distilled water, the granules collected by allowing them to settle, and the supernatant fluid removed. The granules were then suspended in $10 \% \mathrm{KOH}$ for $10 \mathrm{~min}$. at $37^{\circ}$ to remove the adhering pus, washed 7 times in distilled water and preserved in $5 \%$ formaldehyde until used.

The procedure for fixing the granules for ultrathin sectioning was that of Moore \& Chapman (1959). Although initial results were obtained with methacrylate, the use of 'Araldite' (Ciba Ltd) as the embedding medium gave superior preparations. Following fixation, the organisms or granules were passed through $70 \%(\mathrm{v} / \mathrm{v})$ and $90 \%(\mathrm{v} / \mathrm{v})$ ethanol in water for $10 \mathrm{~min}$., three times for $10 \mathrm{~min}$. in absolute ethanol, and were then added to $50 \%(\mathrm{w} / \mathrm{v})$ Araldite in absolute ethanol. The specimens were incubated in the $50 \%$ Araldite solution for $2 \mathrm{hr}$. at $60^{\circ}$, resuspended in $100 \%$ Araldite for $1 \mathrm{hr}$. and placed in fresh Araldite and incubated for 5-8 days before the addition of catalyst. However, later experiments showed that $24 \mathrm{hr}$. was sufficient to give complete penetration of the Araldite into the granule. Sections about $500 \AA$ thick were cut with a Porter-Blum microtome with glass knives prepared in the laboratory and were mounted on copper grids. Electron microscopy was done by using RCA EML and RCA EMU-3F microscopes.

\section{Light and phase microscopy}

The specimens were observed alternately by using the light objective and the medium dark phase attachments of an American Optical Company Microstar microscope having the Polaroid attachments for photography. After each chemical treatment, observations were made with the light and phase objectives. Polaroid photographs were taken by using either no. 53 or no. 55 cut Polaroid film and the negatives of the film developed. The maximum magnification used was $\times 970$; greater magnifications were attained by enlargements from the negatives.

Fixed preparations were prepared and stained by Mr J. P. Pickett (Department of Pathology, Duke University Medical Centre). The Gram reaction, colloidal iron and toluidine blue stains for metachromasia and the alizarin stain for calcium were those given by McManus \& Mowry (1960), the periodic acid Schiff stain was that described by Baker (1957). In addition, wet mounts were made to determine the presence of calcium by using the alizarin procedure.

\section{Chemical methods}

Phosphate was determined originally by the qualitative benzidine test (Feigl, 1956) while the presence of calcium was observed qualitatively by the alizarin procedure given above. Subsequently, phosphate was determined quantitatively by the procedure of Gomori (1942). Calcium was determined quantitatively by Dr R. E. Thiers (Department of Biochemistry, Duke University Medical Centre); 
elementary analyses of the 'sulphur granules' and Actinomyces P2s organisms grown in vitro were done by Galbraith Laboratories Inc. (Knoxville, Tennessee). About 10-12 mg. dry weight of 'sulphur granules' or Actinomyces bovis organisms were combusted in a porcelain crucible to constant weight to determine the ash content; because of limitation of material, only one sample of each was used. In general, the extraction procedures of Park \& Hancock (1960) were used to determine the cellular contents and to prepare the organisms for cell-wall analyses. After the extraction procedure of Park \& Hancock (1960) the organisms were digested and then ruptured with a $20 \mathrm{kc}$. sonifier (Branson Ultrasonic Corp.); cell-wall analyses were done by the procedure of Cummins \& Harris (1956). Metachromasia of extracted phosphate was determined by the procedure of Wiame (1949), reducing sugar by the method of Park \& Johnson (1949) and glucose by the glucostat reagents of Worthington Biochemical Corp. (Freehold, New Jersey). Methylpentoses were determined qualitatively and quantitatively by the procedure of Dische \& Shettles (1948) and quantitatively also by the same procedure as described by Ashwell (1957) with rhamnose as a standard; hexosamine by the procedure of Rondle \& Morgan (1955) with glucosamine as standard, and amino acids by the method of Troll \& Cannan (1953) with alanine as the standard. Sugars were identified qualitatively by one- and two-dimensional chromatography with phenol + water $(70+30$, by vol.) and butanol + pyridine + water $(60+40+30$, by vol.) and were estimated quantitatively by the relative size and colour of the spot obtained with the silver nitrate dip (Trevelyan \& Harrison, 1952) and differentiated from amino sugars by the use of the ninhydrin + acetone dip which was allowed to develop overnight at room temperature. The identification of 6 -deoxy-L-talose rested solely upon the results of MacLennan (1961) who found this sugar in Actinomyces bovis cell walls as the unknown $\mathbf{P}$ component of Cummins \& Harris (1958). The relative high concentration of methylpentose as determined quantitatively with the presence of relative large concentrations of rhamnose and an unknown sugar having an $R_{F}$ value greater than that of rhamnose and somewhat greater than that of 2-deoxyribose in chromatograms with known fucose and rhamnose, were taken as evidence for the presence of 6-deoxy-L-talose.

Amino acids were determined qualitatively with one- and two-dimensional chromatograms with the solvents phenol + water $(70+30$, by vol. $)$ and the top layer of a mixture of butanol + acetic acid + water $(40+10+80$, by vol. $)$. In some cases lutidine + water $(65+35$, by vol.) was also used to discriminate between monobasic and dibasic amino acids. The hydrolysates were chromatographed alone or with aspartic acid, $\beta$-alanine and proline as standards. The latter amino acids were readily determined by their characteristic ninhydrin colours and the relative straight line formed in two-dimensional chromatograms. Identification of the unknown amino acids rested solely on the relative position as determined with these three amino acids, and with other known amino acids, when necessary. The relative quantitative estimation of each amino acid depended on the rate of colour formation, size of spot, and the disappearance of the spots with a decrease in the amount of material applied to the paper.

The effect of lysozyme was determined by the methods of Repaske (1956). Ribonuclease was purchased from Nutritional Biochemical Corp., trypsin and pepsin from Sigma Chemical Co. and lysozyme from Armour \& Co. 


\section{RESULTS}

\section{Morphological aspects}

In general the observations of the granules obtained from the above cases of actinomycosis corresponded to those made by other workers (Conant et al. 1954). Attempts to section a granule in its entirety generally resulted in its partial destruction; either it shattered or was torn from the paraffin. Consequently, the initial results did not provide an adequate cross-section of a complete granule to determine the relative orientation of the layers observed in the fragments. However, when the granules were first extracted with cold $5 \%(\mathrm{w} / \mathrm{v})$ trichloroacetic acid sections were obtained which retained the original outline and in which only the central portions were broken (Pl. 1, fig. 1). When observed in section the granule presented a homogeneous series of inner layers (Pl. 1, figs. 1, 2) in which the individual hyphae were not readily observed unless the Gram staining or the periodic acid-Schiff stain were used, and unless one concentrated on those areas in which fragmentation had occurred (Pl. 1, figs. 1, 2; Pl. 4, fig. 8). The outermost layer consisted exclusively of clubs (Pl. 1, fig. 2). Other aspects of granules in which the orientation of clubs and mycelium are clearly depicted have been reported by Emmons (1935), Conant et al. (1954), Pine et al. (1960), and Pine et al. (1961).

As shown by Pl. 5, figs. 11 and 12, a club might measure from 3 to 20 times the thickness of a mycelial element. Large clubs, when observed in a $10 \%(\mathrm{w} / \mathrm{v}) \mathrm{KOH}$ wet mount, were glassy in appearance and were readily fragmented or shattered with pressure, although when mounted with care in this medium the preparations were found to last for a year or longer with no apparent change. When such mounts were made in lactophenol (Conant et al. 1954) they changed their morphological aspect within several months: the clubs were not readily apparent and the characteristic appearance of the granules and clubs was lost.

Shadowed pseudo-replica preparations of crushed granules observed with the electron microscope showed a very dense central portion in many of the clubs, surrounded by a membranous outer layer (Pl. 2, fig. 3). The dimensions of a club might vary from its tip to its point of attachment with the hypha, but in general there was simply a gradual decrease in diameter until the diameter of the hypha was reached. Although initial attempts to make satisfactory ultrathin sections of clubs failed because of the very hard nature of the granule, several excellent sections were obtained (Pl. 2, figs. 4, 5). In these cases, the club was found to consist of an internal electron-dense hypha surrounded by less dense capsular material. Although the capsule had no definite border, its edge was relatively discrete from the surrounding medium, its internal structure was homogeneous, and structurally it was readily differentiated from the contents of the hypha. Although the clubs themselves were swollen at the tip, the hyphae within them did not show any great enlargement and were normal in their general appearance. The cell walls of the hyphae were readily distinguished from the capsule and internal contents of the cells; in several sections definite cell membranes were observed separated from the cell wall.

In addition, there was observed within many of the cells a very definite crystalline electron-dense material (PI. 3, figs. 6, 7). The presence of this material was variable and was not found in all cells. Similar material was observed in very large quantities 
in the capsules, often completely saturating the cell and the capsule surrounding it (Pl. 2, fig. 4; Pl. 6, fig. 14). In some cases it appeared to originate within the cell (Pl. 3, fig. 6) and could be seen as gradually filling the cell (Pl. 3, figs. 6, 7). As shown in the latter figure, such a cell might exist beside a club which might be totally devoid of the crystalline material. In other cases, the crystalline material appeared to be deposited only on the surface of the cells (Pl. 6, fig. 14). No further analyses of the structural components of the cells or clubs were attempted because of the rigorous treatment given to the material before its fixation.

\section{Histochemical aspects}

Because of questions raised by determinations of the chemical composition of the granules, sections were made and stained for metachromasia and calcium. Comparative preparations of trichloroacetic acid extracted tissue were also made. With the metachromatic stains little difference in coloration was observed as between tissue extracted or not extracted with $5 \%(\mathrm{w} / \mathrm{v})$ trichloroacetic acid. The preparations which were not extracted took the stains badly and were difficult to evaluate because of disintegration of the material. However, Pl. 1 shows the differences in coloration obtained with the colloidal iron stains after extraction with trichloroacetic acid. Plate 1, figs. 1 and 2, in general showed the pink coloration of the granule in the zone of the clubs and the internal layers and the intense blue colour observed in the residual core. Under high magnification however (Pl. 1, fig. 2) many of the clubs also showed a strong blue coloration while others remained pink. Although this result is suggestive of mucopolysaccharide, mucopolysaccharide was not indicated by subsequent chemical analyses. As a consequence of these observations and of results obtained with toluidine blue, it can only be stated that many of the clubs contain polysaccharide with an affinity for iron, but the general composition of the clubs themselves is not clearly revealed by these stains. When stained with the periodic acid-Schiff stain, the granule in general took a light pink stain. Upon examination of the central portion under high power, it was seen that the mycelial elements themselves had stained a deep red and were apparently embedded in a cementing substance similar in colour to that of the clubs (P1. 4, fig. 8). These results suggested a difference in chemical composition between the capsular material and the cell walls of the organism.

Because of the results obtained by chemical analyses, fixed and wet mounts were prepared and stained for calcium. As shown by Pl. 4, fig. 9, the brilliant red of the alizarin was readily apparent at the surface of the mycelial filaments but it brought out in very strong contrast the large calcium deposits apparent in the clubs themselves (Pl. 4, fig. 10).

\section{Chemical analyses and concomitant changes as observed with light and phase microscope}

The basis for much of the preceding and the subsequent analyses rests primarily on several preliminary observations. The very hard gritty nature of the granule itself suggested the possibility of a mineral deposit. A qualitative ashing of several granules on the end of a spatula revealed a very high volume of ash. A benzidine spot test for phosphate showed that the ash contained a very high concentration 
of phosphate, much greater than that observed for a similar amount of organism grown in vitro. Moreover, it was observed that the granules and the clubs were quite resistant to the effects of $10 \%(\mathrm{w} / \mathrm{v}) \mathrm{KOH}$ but changed and became translucent in the lactophenol mounts. These results suggested that lactophenol was extracting some major components of the granules, while the resistance of the clubs to strong base indicated that the basal structure of the club was polysaccharide in nature. Finally, observation with the phase microscope of granules in semipermanent lactophenol mounts showed with amazing clarity that virtually all the clubs contained an apparently normal internal hypha. In $\mathbf{K O H}$, water or glycerol mounts the use of the phase microscope revealed nothing which was not readily observed with the light microscope. Further investigation showed that extraction with $80 \%(\mathrm{v} / \mathrm{v})$ lactic acid, $88 \%(\mathrm{w} / \mathrm{v})$ phenol, or $10 \%$ trichloroacetic acid also made the hyphae visible with phase contrast. In addition the latter so altered the clubs, that much of the capsular material could be stripped off with gentle tapping on the coverslip of wet mounts; in some cases, the internal hypha was observed to slip free of the capsule surrounding it.

Consequently, comparative analyses of the granules from actinomycosis case $\mathbf{P} \mathbf{2}$ and the in vitro-grown organisms of the corresponding isolate (Actinomyces bovis P 2 S) were undertaken by using the extraction procedures of Park \& Hancock (1960). Table 1 shows the relative concentration of phosphorus in the four fractions. Of the total phosphorus extracted by cold trichloroacetic acid, $92 \%$ was inorganic phosphate, consequently large amounts of teichoic acids were not present in this fraction. Determination of the index of metachromasia (Wiame, 1949) showed that the trichloroacetic acid-extracted phosphate of the granules was not metachromatic. Comparative elementary chemical analyses are given in Table 2.

Table 1. Relative amounts of total phosphorus extracted from cells of Actinomyces bovis and sulphur granules by different consecutive procedures*

Procedure

A. bovis Sulphur granule (\% of dry wt.) (\% of dry wt.)

Cold $5 \%(\mathrm{w} / \mathrm{v})$ trichloroacetic acid Aqueous ethanol

Hot $5 \%(w / v)$ trichloroacetic acid Trypsin-solubilized

$\begin{array}{lc}0.5 & 10.8 \dagger \\ 0.0 & 0.0 \\ 0 \cdot 1 & 0.0 \\ 0.6 & 0.0\end{array}$

* Based upon the procedure of Park \& Hancock (1960) the cells and granules (12 mg./ml.) were first extracted with cold trichloroacetic acid for 10 min., washed 3 times in water with centrifugation, extracted with trichloroacetic acid for 6 min. at $90^{\circ}$, washed 3 times with water, and then subjected to trypsin digestion for $6 \mathrm{hr}$. at $37^{\circ}$ as described by these workers.

$\dagger$ The total inorganic phosphorus found in this extract was $10.0 \%$.

About $\mathbf{9} \%$ phosphorus and $\mathbf{5 6 \cdot 6} \%$ ash were found in the granules as compared to 1 and $9.3 \%$ found in the cells, respectively. In the ash of the granule, calcium constituted an average of $29 \%(\mathrm{w} / \mathrm{w})$ and could represent as much as $75 \%(\mathrm{w} / \mathrm{w})$ $\mathrm{Ca}_{3}\left(\mathrm{PO}_{4}\right)_{2}$; on the basis of calculations the $\mathrm{Ca}_{3}\left(\mathrm{PO}_{4}\right)_{2}$ is estimated between $39 \cdot 1$ and $56.5 \%(\mathrm{w} / \mathrm{w})$ of the sulphur granule; sodium and potassium phosphate with other salts most probably account for the remaining ash. Assuming the phosphorus of present as pure calcium phosphate and correcting the analyses of both materials for 
the presence of phosphate, the analyses of the granules gave a crude formula of $\mathrm{C}_{4 \cdot 1} \mathrm{H}_{8 \cdot 6} \mathrm{O}_{2 \cdot 0} \mathrm{~N}_{0 \cdot 8}$ whereas that of the in vitro-grown organisms of Actinomyces bovis was $\mathrm{C}_{4 \cdot 1} \mathrm{H}_{7 \cdot 6} \mathrm{O}_{2 \cdot 1} \mathrm{~N}_{0 \cdot 7}$. These analyses suggest that there is no major difference in the chemical composition between the in vitro-grown organisms and that of the sulphur granules, with the exception of the high percentage of calcium phosphate in the granules.

Table 2. Elementary analyses of dried organisms of Actinomyces bovis and its in vivo formed sulphur granules

\begin{tabular}{|c|c|c|}
\hline Analysis & $\begin{array}{c}\text { Actinomyces } \\
\text { bovis } \\
(\%)\end{array}$ & $\begin{array}{c}\text { Sulphur } \\
\text { granule } \\
(\%)\end{array}$ \\
\hline Carbon & $45 \cdot 10$ & $21 \cdot 22$ \\
\hline Hydrogen & 6.94 & $3 \cdot 72$ \\
\hline Nitrogen & $8 \cdot 22$ & $4 \cdot 98$ \\
\hline Phosphorus & 1.00 & $9 \cdot 07$ \\
\hline Sulphur & Trace & Trace \\
\hline Ash & $9 \cdot 3$ & $56 \cdot 6$ \\
\hline $\begin{array}{l}\mathrm{Ca}_{3}\left(\mathrm{PO}_{4}\right)_{2} \text { calculated on } \\
\text { the basis of } \mathrm{P}\end{array}$ & nd* & $56 \cdot 5$ \\
\hline Calcium of ash & nd* & $29 \cdot 0$ \\
\hline $\begin{array}{l}\mathrm{Ca}_{3}\left(\mathrm{PO}_{4}\right)_{2} \text { calculated on } \\
\text { basis of } \mathrm{Ca} \text { of ash }\end{array}$ & nd* & $39 \cdot 1$ \\
\hline
\end{tabular}

Table 3. Quantitative analyses of cell-wall residues of sulphur granules and organisms of Actinomyces bovis after sulphuric acid hydrolysis*

$\mu$ mole $/ 100$ mg. dry wt. of whole organ
corrected for the \% ash

* Hydrolysis procedure was that of Cummins \& Harris (1956). Original samples were $54 \cdot 4 \mathrm{mg}$. of sulphur granules, and $40 \cdot 2 \mathrm{mg}$. of organisms grown in vitro, containing $56 \cdot 6$ and $9 \cdot 3 \%$ ash, respectively. Amino acids were determined with alanine as a standard.

The cell-wall residues remaining after the extraction procedures of Park \& Hancock (1960) were hydrolysed according to the procedure of Cummins \& Harris (1956) after additional treatment with pepsin and ribonuclease as described by the latter workers. Experiments were done on cells broken by sonification for $10 \mathrm{~min}$. with a 20 kc. sonifier (Heat Systems Corp., Great Neck, New York). After the preliminary drying of the organisms by the Park \& Hancock procedure (1960), the foregoing treatment was adequate to fragment and disrupt completely all the organisms. However, the subsequent extraction procedures and treatment with enzymes were not completely effective in removing protein adherent to the cell walls, as shown by electron microscopic observation.

After hydrolysis of separate samples, the cell wall residues were analysed for 
sugars and amino acids. The results of one group of analyses are given in Table 3. The data show that the sulphur granules had a significantly higher amount of hexosamine and amino acids and had approximately $7.5 \%$ more reducing sugar not accountable as glucose or hexosamine. The higher concentration of reducing compounds and amino acids in the sulphur granules suggests a major difference in the two materials not indicated by the results of chromatographic analyses. The results of chromatographic separation and gross quantitative estimation of the sugars and amino acids in cell walls of sulphur granules and organisms are given in Table 4.

Table 4. Comparative qualitative sugar and amino acid analyses of the cell-wall residues of sulphur granules and organisms of Actinomyces bovis

\begin{tabular}{|c|c|c|c|c|}
\hline Analyses & \multicolumn{2}{|c|}{ Sulphur granule } & \multicolumn{2}{|c|}{ Actinomyces bovis } \\
\hline \multicolumn{5}{|l|}{ Sugars: } \\
\hline Glucose & \multicolumn{2}{|c|}{+3} & \multicolumn{2}{|c|}{+5} \\
\hline Galactose & \multicolumn{2}{|c|}{+3} & \multicolumn{2}{|c|}{+1} \\
\hline Fucose & \multicolumn{2}{|c|}{ - } & \multicolumn{2}{|c|}{ Trace } \\
\hline Rhamnose & \multicolumn{2}{|c|}{+5} & \multicolumn{2}{|c|}{+3} \\
\hline 6-Deoxytalose & \multicolumn{2}{|c|}{+4} & \multicolumn{2}{|c|}{$+\mathbf{3}$} \\
\hline Glucosamine & \multicolumn{2}{|c|}{ Trace } & \multicolumn{2}{|c|}{+1} \\
\hline Galactosamine & \multicolumn{2}{|c|}{+1} & \multicolumn{2}{|c|}{ Trace } \\
\hline Amino acids : & $*$ & $\dagger$ & $*$ & $\dagger$ \\
\hline Alanine & +8 & +5 & +10 & +5 \\
\hline Glutamic & +3 & +3 & +3 & +2 \\
\hline Aspartic acid & +2 & +5 & +3 & +5 \\
\hline Lysine & +2 & +2 & +2 & +2 \\
\hline Valine & +2 & + & +2 & + \\
\hline Arginine & +1 & - & +1 & - \\
\hline Glycine & + & - & + & - \\
\hline \multicolumn{5}{|l|}{ Serine: } \\
\hline Serine & + & - & + & - \\
\hline Threonine & + & - & + & - \\
\hline $\begin{array}{l}\text { Leucine, isoleucine } \\
\text { phenylalanine }\end{array}$ & +3 & - & +2 & - \\
\hline
\end{tabular}

Again there was a close similarity in the qualitative compositions of the products released on hydrolysis. The high concentration of methylpentoses as observed in two-dimensional chromatograms is in accord with the quantitative determinations of Table 3. However, very little hexosamine was observed in the chromatograms, and although the quantitative value is low in Table 3, the amount reported may still be high because of contamination of the walls with cellular protein during hydrolysis (Boas, 1953; Eddy, 1958). Repeated chromatography of amino acids revealed no significant differences, qualitatively or quantitatively, as between organisms and granules. The fact that essentially all the major amino acids were represented by ninhydrin spots is attributed to the contamination of the walls with protein. But it can be seen in Table 4 that alanine, glutamic acid, aspartic acid, lysine and arginine constituted the major amino acids, while leucine, isoleucine and phenylalanine were also present. By decreasing the quantity of material placed on the paper and by using different solvents it was found that the major 
amino acids were alanine, glutamic acid, aspartic acid and lysine. On the basis of these results it was concluded that there was little gross difference between the cell wall composition of organisms grown in vitro and that of cell walls and capsular material of granules formed in vivo.

However, the combined results suggested that there was a difference between the cell wall of mycelium in the granule and the capsular material forming the club. Previous results suggested the possibility of using lysozyme to distinguish between the capsular material and the cell wall. Consequently, about a dozen large granules $(0.5-1.0 \mathrm{~mm}$. diameter) were picked and extracted in about $3 \mathrm{ml}$. of each solvent as given by Park \& Hancock (1960). These were then treated with trypsin, ribonuclease and pepsin by the method of Cummins \& Harris (1956) but without disruption by sonification. At each step a few granules were removed for observation with the light and phase microscopes, with lactophenol, glycerol or water as mounting medium. The effect of such treatment on the organisms and clubs of the granules is shown in $\mathrm{Pl} .5$, fig. 11; the clubs remained intact but the cells and the internal filaments changed. In Pl. 5, fig. 11, an extremely large club is seen in which the internal filament is visible in water suspension. No other clubs showing the internal filaments were observed in the water mounts. The granules were then subjected to lysozyme treatment for several hours, with no visible effect; nor did extraction of the granules with $3 \mathrm{ml} .88 \%(\mathrm{w} / \mathrm{v})$ phenol in water for $10 \mathrm{~min}$. at $100^{\circ}$ render them sensitive to lysozyme. However, results with organisms of Actinomyces bovis, $A$. naeslundii and $A$. israelii showed these were not sensitive to lysozyme unless the organisms were extracted with $10 \%(\mathrm{w} / \mathrm{v}) \mathrm{KOH}$ for $10 \mathrm{~min}$. at $100^{\circ}$ (Pine, unpublished results). The remaining granules were then subjected to such a treatment and were re-examined with the light and phase microscopes. After the KOH treatment, the capsular material became sufficiently transparent so the internal hypha was now visible in water mounts with the light microscope, although it was much more obvious with the phase microscope (Pl. 5, figs. 12, 13). A ninhydrin spot test on the neutralized KOH extract showed the presence of significant amounts of ninhydrin-reacting material. Because of the relative absence of hexosamines in the cell wall analyses and because of the effect of $\mathrm{KOH}$ on carbohydrate protein complexes (Eddy, 1958) these compounds are assumed to be amino acids or degradation products of proteins.

Such KOH-treated cells when subjected to lysozyme became flexible and limp and then disintegrated into fragments within an hour. Essentially the same results were obtained with granules, and the mycelial elements appeared to agglutinate into a limp flexible mass. Although the clubs still remained intact they too became quite flexible with the capsules less sensitive to lysozyme than the cells they contained. It is concluded that the capsule is polysaccharide containing bound protein and having essentially the same basic chemical structure as the cell wall of Actinomyces bovis, but probably differing in linkage groups and the presence of unknown amino acids.

\section{Ultrathin sections and the effect of trichloroacetic acid}

Although the results presented above suggested some difference between club and capsule, the greatest difference observed was between the phosphate content of the granule and of organisms grown in vitro. Therefore the effect of trichloroacetic 
acid was investigated by comparing ultrathin sections from extracted and unextracted granules; the results are shown in Pl. 6. The electron-dense material initially observed was absent after extraction (Pl. 6, figs. 14, 15). Observation of Pl. 6, fig. 14, shows that phosphate was exceedingly dense toward the central regions of the granule, that it might completely penetrate the cell and its capsule, or might just coat the surface of some cells. Plate 6, fig. 15, clearly shows the cementing polysaccharide left after extraction, but with many cells in various stages of atrophy or malformation. This abnormal appearance of the cells was consistently observed in the deeper sections of the granule. On the other hand, Pl. 6, fig. 16 clearly shows polysaccharide as a capsule surrounding normal hyphae with normal cell walls. In some cases, however, no internal hypha was evident, and it was assumed that the cell had disintegrated. Observation of the morphological appearance of the cementing substance (Pl. 6, fig. 17) and the capsular material (Pl. 6, fig. 18) suggests they are of similar composition. From Pl. 6, figs. 14-16, it is concluded that the electrondense material initially observed was calcium phosphate. It is also concluded that the capsular material is present in the granules in sufficiently high concentration to alter grossly the chemical analyses from that of organisms grown in vitro if a major difference in chemical composition existed. Consequently, it is concluded that the club and cementing material are of bacterial origin.

\section{DISCUSSION}

When first observed, the pseudo-replicas such as shown in Pl. 2, fig. 3, were interpreted as showing a swollen hypha in which the cytoplasm had contracted leaving a border of collapsed cell wall. But such an interpretation was completely inconsistent with the observations made with the phase microscope and made it impossible to interpret the observations made of the initial ultrathin sections. Under the most adverse conditions in culture or within the granule, the maximum diameter of swollen hyphal ends seldom exceeded twice that of the normal hypha. A constant regard to comparative size (observe the hypha of the club of Pl. 2, fig. 4, which is of the same outline but approximately half the size of the club in Pl. 2, fig. 3), the fact that most enlarged filaments were found to contain normal hyphae in capsules, and the fact that no other interpretation was compatible with all the observations indicated that the outer membrane in such pseudo-replicas was capsular material and not the cell wall.

From the above results it is apparent that the sulphur granule and the organism grown in vitro have essentially the same qualitative chemical composition with the exception of the high proportion of calcium and phosphorus in the granule. Because of the high concentration of cementing substance and capsule observed with the electron microscope after trichloroacetic acid extraction one would expect a major chemical difference between the granule and the organism grown in vitro if such a difference existed. From the chemical analyses, this appeared not to be the case; it is concluded that the club is truly a capsule surrounding the hypha and is not of animal origin. This conclusion was suggested first by Knaysi (1951).

It is recognized that there are a few minor differences in cell wall analyses of Actinomyces bovis as reported here and as reported by Cummins \& Harris (1958). Glucose was not reported in the cell walls of organisms grown in vitro but, as seen 
from Table 3, it is a relatively minor reducing sugar. Virtually no fucose was found; the major methyl sugars observed were rhamnose and the $\mathbf{P}$ component, the latter being most probably 6-deoxy-L-talose (MacLennan, 1961). Otherwise the sugar and amino acid analyses are in agreement with the results of Cummins \& Harris (1956, 1958, 1959) and Cummins (1962) and re-emphasize the probable bacterial origin of the club and granule material.

Concerning the chemical analyses, the high concentration of phosphate found in the granules is of the greatest interest; its source is unknown but it is of interest to relate this observation with the results of several other workers. Howell \& Fitzgerald (1953) showed acid phosphatase activity in Actinomyces israelii and $A$. naeslundii and Citron (1945) reported on the alkaline phosphatase activity of species of Actinomyces. Rizzo, Martin, Scott \& Mergenhagen (1962) found that the dead organisms of Actinomyces and other bacterial species strongly absorbed calcium phosphate of the animal and deposited it in the form of hydroxyapatite. Also, the high concentration of phosphatase in wound tissue or in histocytes and macrophages (Gomori, 1943; Carranza \& Cabrini, 1962) probably plays an important role in tissue infected with Actinomyces.

It may be suggested that formation of the granule occurs as follows. Since the capsule is not generally formed in vitro it is postulated that it is formed as a consequence of the growth of Actinomyces in the host. As a result of the organism's enzymic activity and the enzymic activity of the host cells, phosphate is released into the area of the mycelial mass. Because of the chemical nature of the cell wall and the capsule, the phosphate is deposited as calcium phosphate on the surface of the cells, sometimes within the cells. As a result of progressive mineralization of the capsule many of the cells became atypical in morphology and die; eventually the central portion of the granule becomes completely impregnated and solidified.

Such an interpretation is supported by the results and photographs of Rizzo et al. (1962). These workers observed that calcification seemed to follow the individual outlines of the organisms and that mineralization might occur adjacent to or within the organisms incubated in dialysis tubing implanted in rats. They also observed that dead cells were much more rapid in their mineralization than were viable cells. The results of these workers might have a direct application to the results and interpretations reported here.

The authors acknowledge the many helpful suggestions and constructive criticisms of Dr Robert W. Wheat (Department of Biochemistry, Duke University Medical Centre, Durham, North Carolina) and Dr Abe Widra (Department of Bacteriology, University of North Carolina, Chapel Hill, North Carolina) during the course of these investigations. This work was supported by U.S.P.H.S. Grants: E-1866 (C4); E-2035 (C3); SF-64-C4 and 2E-31, National Institutes of Health, Bethesda, Maryland. 


\section{REFERENCES}

Asuweld, G. (1957). Colorimetric analyses of sugars. Methods in Enzymology, vol. 3. Ed. by S. P. Colowick and N. O. Kaplan. New York: Academic Press.

BAKER, R. D. (1957). Diagnosis of fungus diseases by biopsy. J. chron. Dis. 5, 552.

Boas, N. F. (1953). Method for the determination of hexosamines in tissues. J. biol. Chem. 204, 553.

Bollinger, O. (1877). Über eine neue Pilzkrankheit beim Rinde. Zbl. med. Wiss. $10,481$.

Buchanan, B. B. (1962). Studies on the physiology and metabolism of Actinomyces naeslundii. Ph.D. Thesis, Duke University.

Carranza, F. A., Jun. \& Cabrini, R. L. (1962). Histo-chemical distribution of acid phosphatase in healing wounds. Science, 135, 672.

Citron, S. R. (1945). The role of Actinomyces israeli in salivary calculus formation. J. dent. Res. 24, 87 .

Cohn, F. (1875). Untersuchungen über Bacterien. Beitr. Biol. Pfl. $2,186$.

Conant, N. F., Smith, D. T., Baker, R. D., Callaway, J. L. \& Martin, D. S. (1954). Manual of Clinical Mycology, 2nd ed. Philadelphia: W. B. Saunders Company.

Cromartie, W. J., Spitznagel, J. K. \& Crawford, J. J. (1960). Role of basic proteins in natural resistance to infection. II. Participation of basic proteins in host parasite interaction in actinomycosis. J. Elisha Mitchell Sci. Soc. 76, 199.

Cummins, C. S. \& Harris, H. (1956). The chemical composition of the cell wall in some Gram-positive bacteria and its possible value as a taxonomic character. J.gen. Microbiol. 14, 583.

Cummins, C. S. \& Harris, H. (1958). Studies on the cell-wall composition and taxonomy of Actinomycetales and related groups. J. gen. Microbiol. 18, 173.

Cummins, C. S. \& Harris, H. (1959). Cell-wall composition in strains of Actinomyces isolated from human and bovine lesions. J. gen. Microbiol. 21, ii.

Cummins, C.S. (1962). Chemical composition and antigenic structure of cell walls of Corynebacterium, Mycobacterium, Nocardia, Actinomyces and Arthrobacter. J. gen. Microbiol. 28, 35.

Dische, Z. \& Shetrles, L. B. (1948). A specific color reaction of methyl pentoses and a spectrophotometric micromethod for their determination. J. biol. Chem. 175, 595 .

Epdy, A. A. (1958). The structure of the yeast cell wall. Ir. Degradative studies with enzyme. Proc. Roy. Soc. B, 149, 425.

Emmons, C. W. (1935). Actinomyces and actinomycosis. Puerto Rico J. publ. Hlth, 11, 63.

Feigl, F. (1956). Spot Tests in Organic Analysis, 5th ed. New York: Elsevier Publishing Co.

Gomori, G. (1942). A modification of the colorimetric phosphorus determination for use with the photoelectric colorimeter. J. Lab. clin. Med. 27, 955.

Gomori, G. (1943). Calcification and phosphatase. Amer. J. Path. 19, 197.

Harz, C. O. (1879). Actinomyces bovis: ein neuer Schimmel in den Geweben des Rindes. Dtsch. Z. Tiermed. 5, 125.

Howell, A., Jun. \& Fitzgeratd, R. J. (1953). The production of acid phosphatase by certain species of Actinomyces. J. Bact. 66, 437.

IsraEL, J. (1878). Neue Beobachtungen auf dem Gebiete der Mykosen des Menschen. Virchows Arch. 74, 15.

KNaysi, G. (1951). Elements of Bacterial Cytology, 2nd ed. Ithaca: Comstock Publishing Company, Inc.

MacLennan, A. P. (1961). Composition of the cell wall of Actinomyces bovis. The isolation of 6-deoxy-L-talose. Biochim. biophys. Acta, 48, 600.

McManus, J. F. A. \& Mowry, R. W. (1960). Staining Methods, Histologic and Histochemical. New York: Paul B. Baeber, Inc. Medical Division of Harpers and Brothers.

Moone, R. T. \& Chapman, G. B. (1959). Observations of the fine structure and modes of growth of a streptomycete. J. Bact. 78, 878 .

Park, J. T. \& Johnson, M. J. (1949). A submicrodetermination of glucose. J. biol. Chem. $149,51$. 
Park, J. T. \& Hancock, R. (1960). A fractionation procedure for studies of the synthesis of cell-wall mucopeptide and of other polymers in cells of Staphylococcus aureus. J. gen. Microbiol. 22, 249.

Pine, L., Howell, A., Jun. \& Watson, S. J. (1960). Studies of the morphological, physiological, and biochemical characters of Actinomyces bovis. J. gen. Microbiol. 23, 403.

Pine, L., Shearin, W. A. \& Gonzales, C. A. (1961). Mycotic flora of the lacrimal duct. Amer. J. Ophthal. 52, 619.

Pine, L. \& Watson, S. J. (1959). Evaluation of an isolation and maintenance medium for Actinomyces species and related organisms. J. Lab. clin. Med. 54, 107.

Ponfick, E. (1880). Über Actinomykose. Berl. klin. Wschr. 17, 660.

Repaske, R. (1956). Lysis of Gram-negative bacteria by lysozyme. Biochim. biophys. Acta, 22, 189.

Rizzo, A. A., Martin, G. R., Scott, D. B. \& Mergenhagen, S. E. (1962). Mineralization of bacteria. Science, 135,439 .

Rondue, C. J. M. \& Morgan, W. T. J. (1955). Determination of glucosamine and galactosamine. Biochem. J. 61, 586.

Trevelyan, W. E. \& Harrison, J. S. (1952). Fractionation and microdetermination of cell carbohydrates. Biochem. J. 50, 298.

Troll, W. \& Cannan, R. K. (1953). A modified photometric ninhydrin method for analysis of amino and imino acids. J. biol. Chem. 200, 803.

Wiame, J. M. (1949). The occurrence and physiological behavior of two metaphosphate fractions of yeast. J. biol. Chem. 178, 919 .

Wright, J. H. (1905). The biology of the microorganisms of actinomycosis. J. med. Res. 13, 349.

\section{EXPLANATION OF PLATES}

Prate 1. Morphological aspects of the 'sulphur granule'. Colloidal iron stain

Fig. 1. Granule enlarged to show the various layers differentially stained and showing the relatively dark staining layer of clubs. $\times 100$.

Fig. 2. Same granule showing the peripheral arrangement of the clubs. $\times 430$. Sections were prepared from a granule after extraction with $5 \%(w / v)$ trichloroacetic acid.

Plate 2. Morphological aspects of the granules formed by Actinomyces bovis as observed with the electron microscope

Fig. 3. Club, chromium shadowed. $\times 12,200$.

Fig. 4. Ultrathin section of clubs, showing capsular material surrounding normal appearing hypha. Note capsules below containing electron dense material. $\times 20,000$.

Fig. 5. Ultrathin section of club showing diffuse nature of capsule surrounding a more electron dense cell-wall of a normal appearing hypha. $\times \mathbf{2 4 , 0 0 0}$.

Plate 3. Morphological aspects of the cells within the granules formed by Actinomyces bovis as observed in ultrathin sections

Fig. 6. Section showing the crystalline nature of the electron dense material deposited within cells. Upper left, mother cell is completely filled while the bud remains free of the deposit. Second cell (right) appears to be relatively free of the deposit in the central area whereas area bordering the cell wall is saturated. $\times \mathbf{3 5 , 0 0 0}$.

Fig. 7. Section of the granule showing various aspects of cell morphology. Note single cell heavily impregnated with crystalline material and situated next to an encapsulated cell without crystalline material. $\times 35,000$.

Plate 4. Histochemical aspects of the 'sulphur granule'

Fig. 8. Periodic acid-Schiff stain of a fragment of the granule showing the pink cementing material of the granule containing the red hyphal elements. Granule was extracted with $5 \%(w / v)$ trichloroacetic acid. 
Journal of General Microbiology, Vol. 32, No. 2

Plate 1
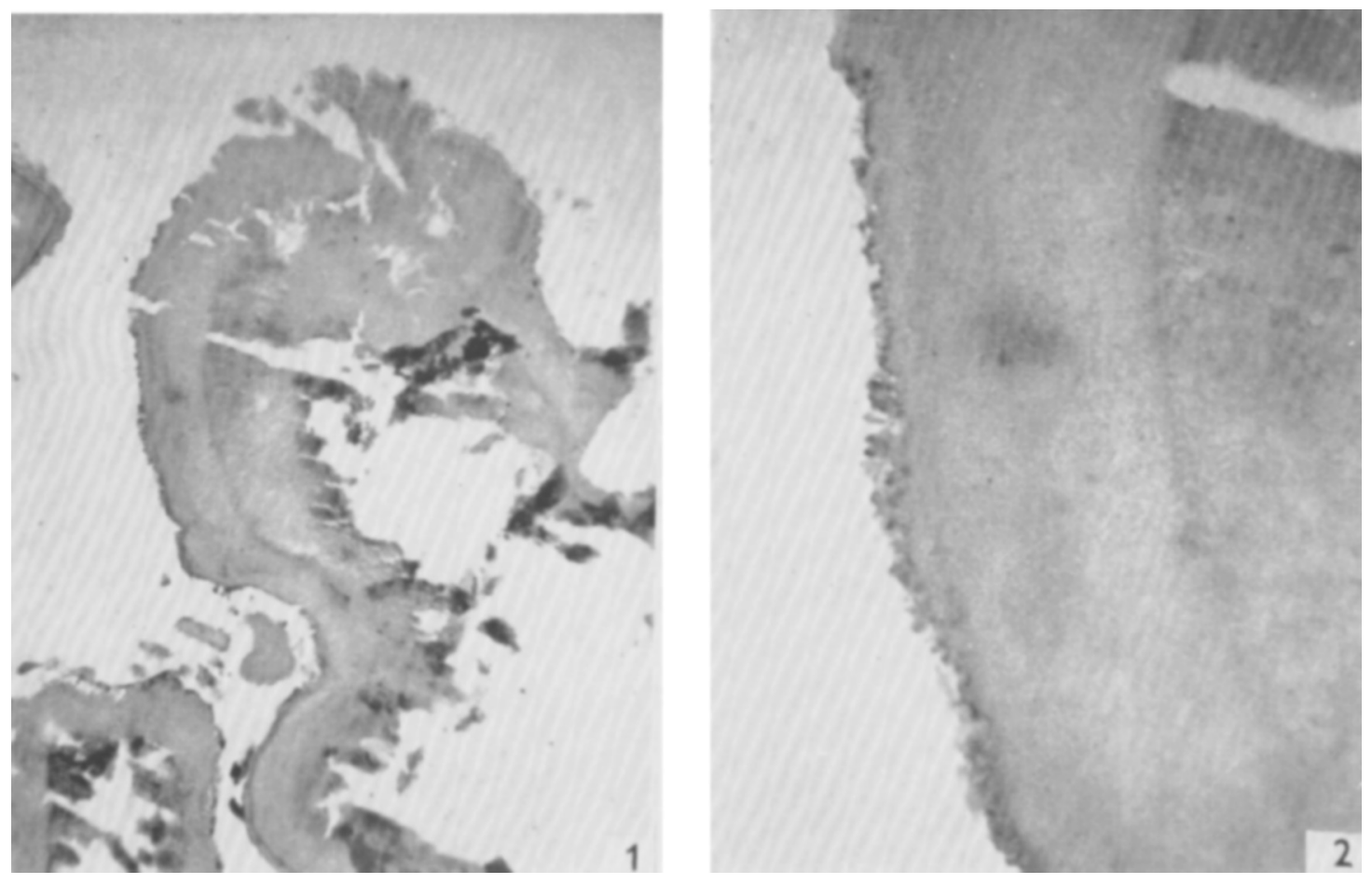

L. PINE AND J. R, OVERMAN

(Facing p. 222) 
Journal of General Microbiology, Vol. 32, No. 2

Plate 2

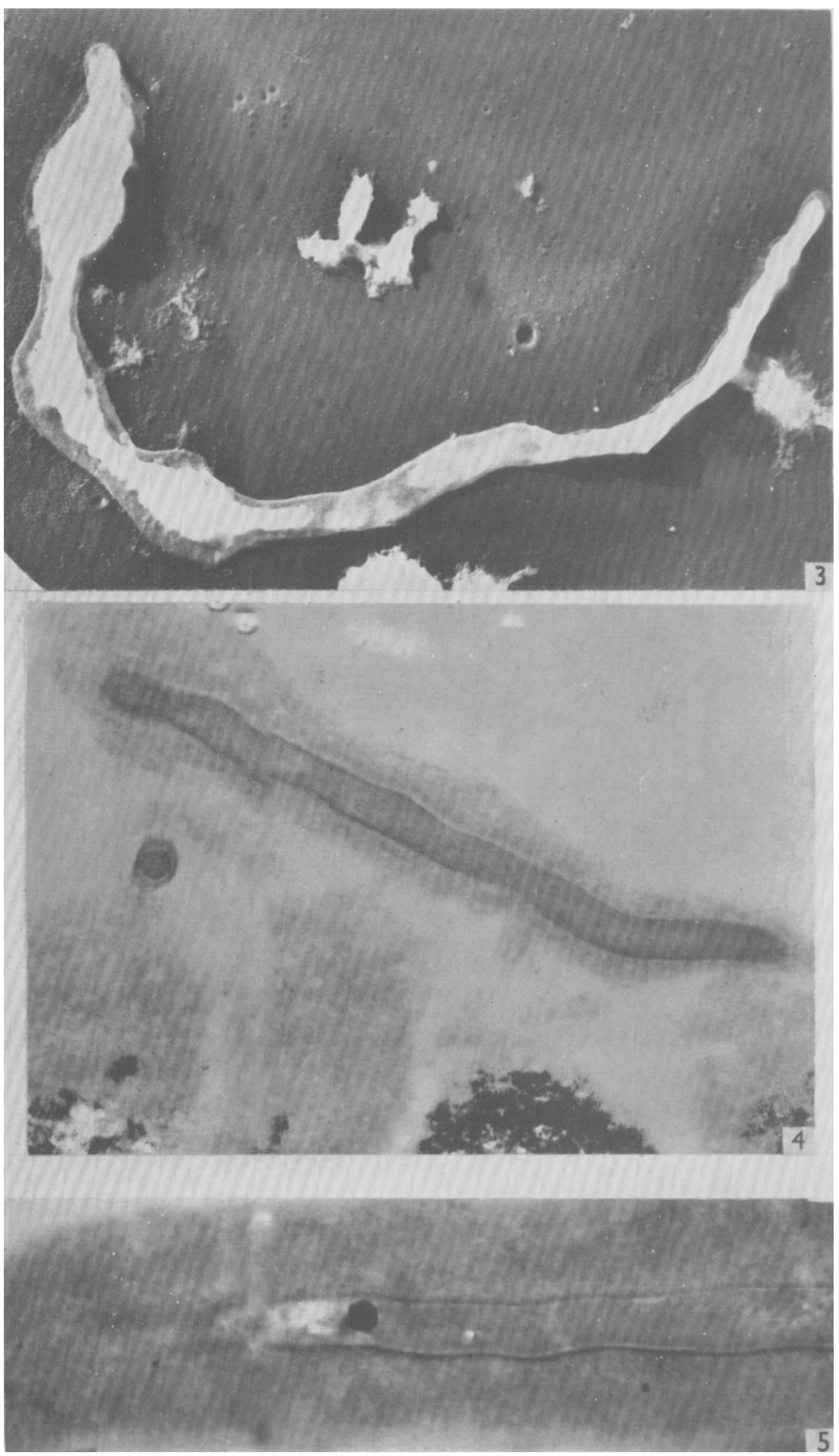

I. PINE AND J. R. OVERMAN 

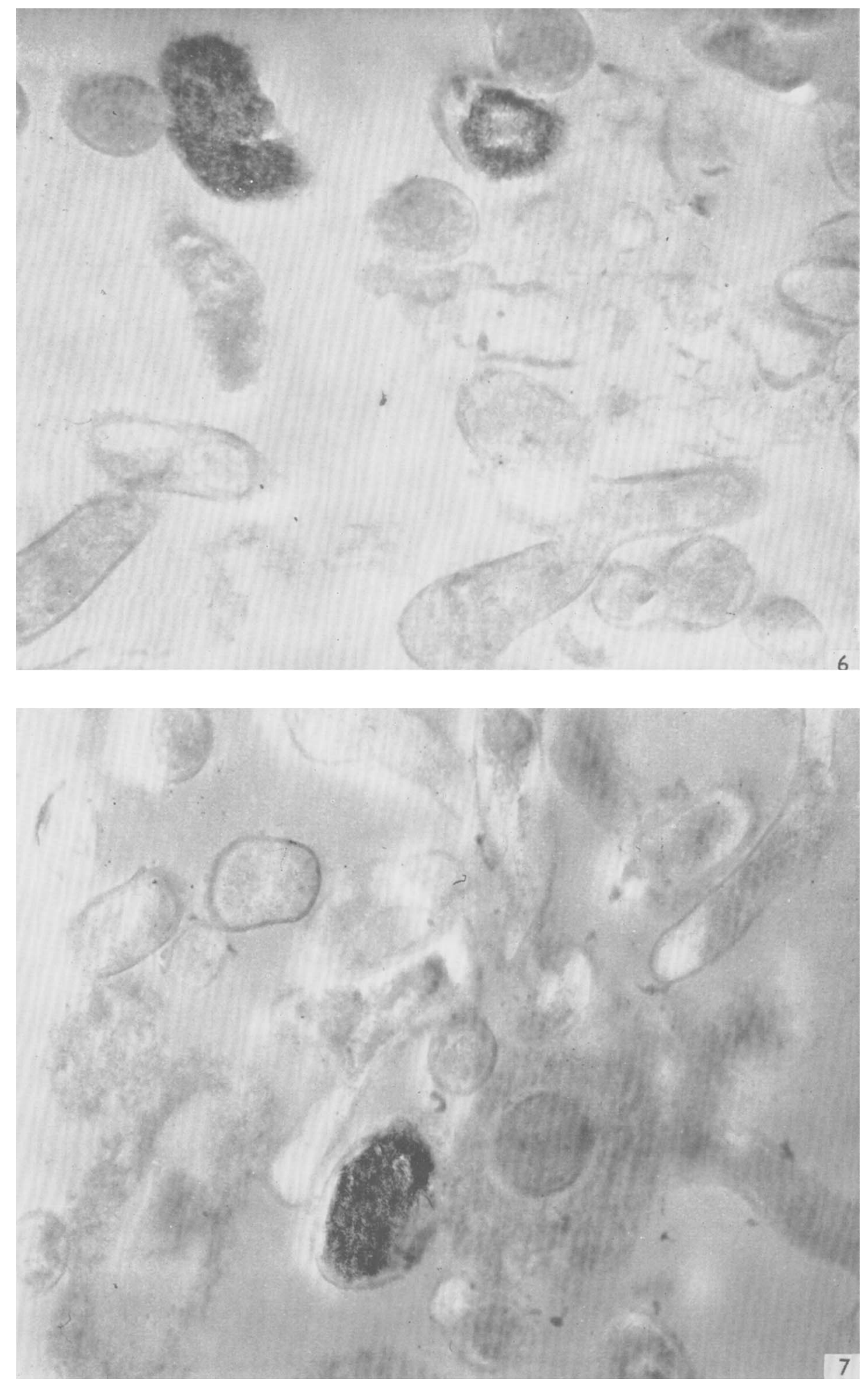

L. PINE AND J. R. OVERMAN 

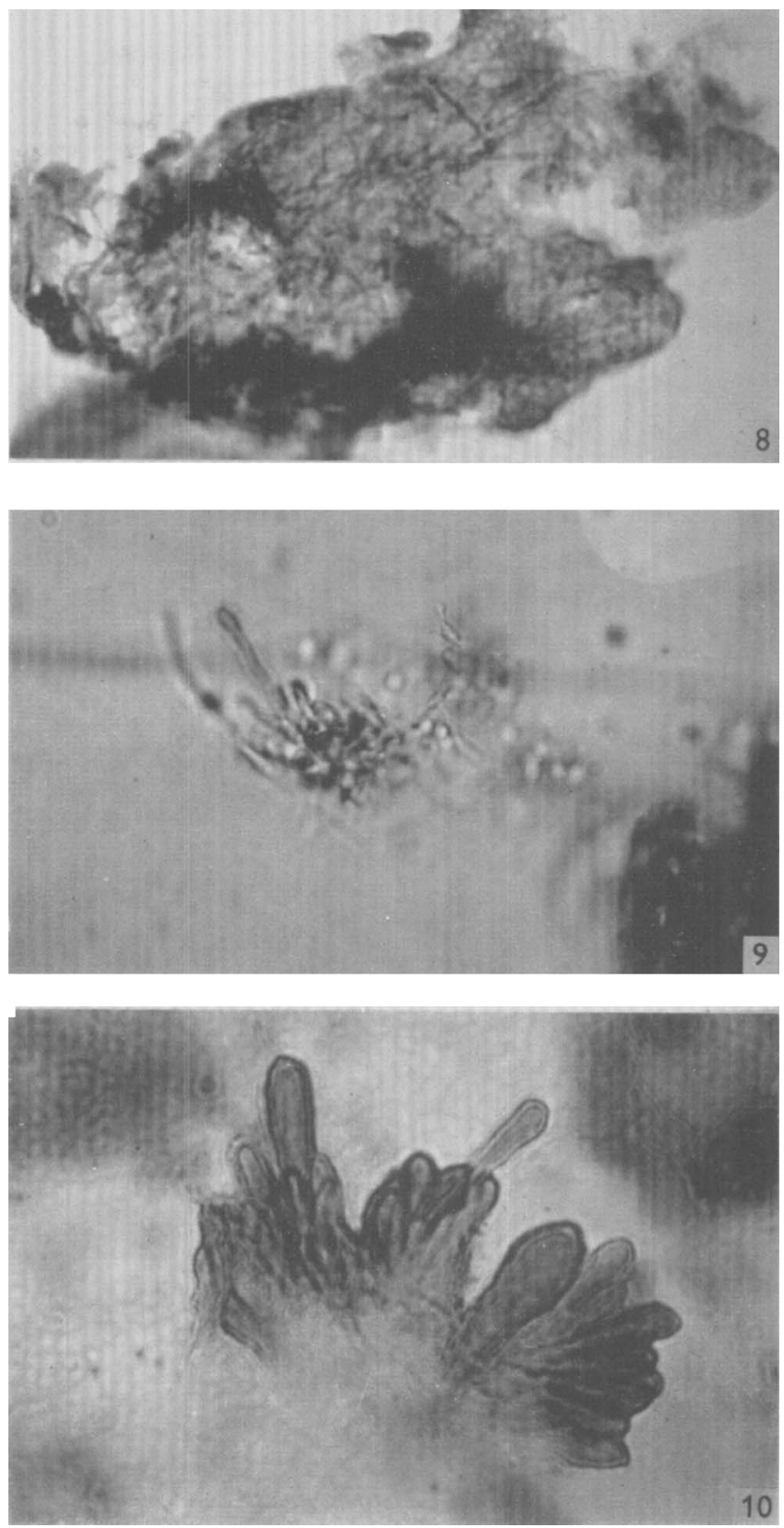

L. PINE AND J. R. OVERMAN 

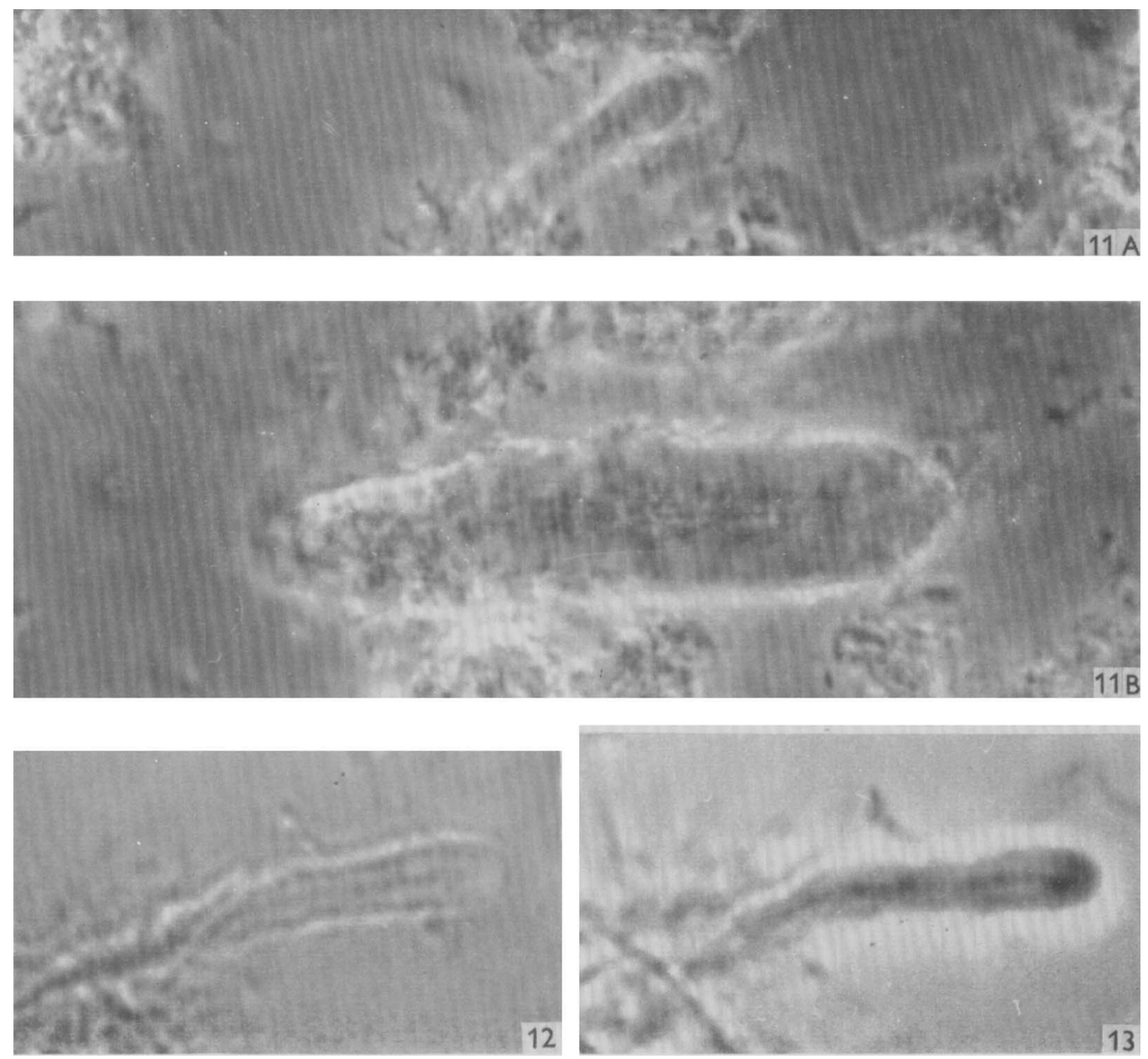

L. PINE AND .J. R. OVERMAN 
Journal of General Microbiology, Vol. 32, No. 2

Plate 6
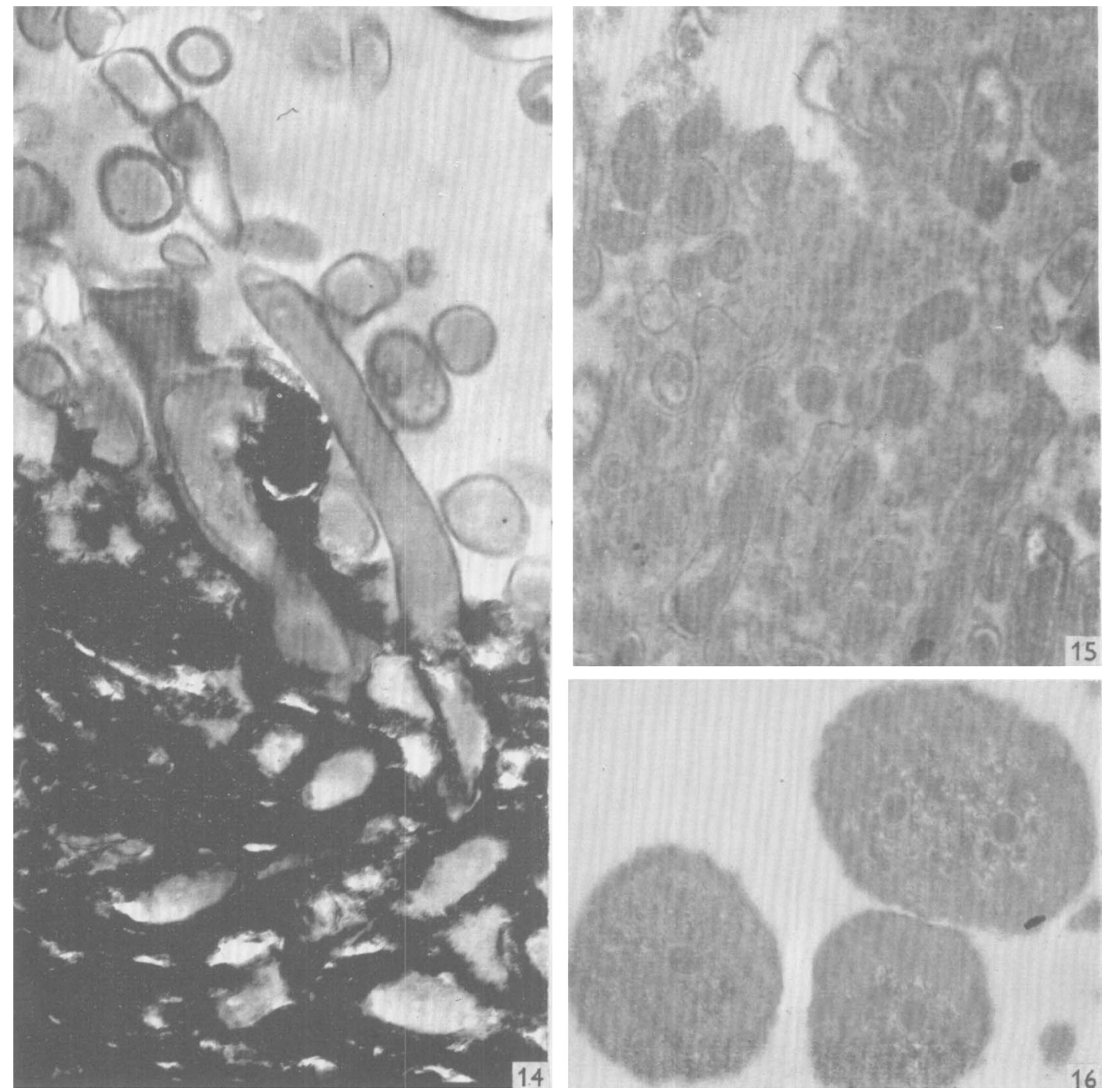

L. PINE AND J. R. OVERMAN 


\section{'Sulphur granules' of Actinomyces bovis}

Fig. 9. Wet mount alizarin red stain of mycelial elements from crushed granule showing the presence of calcium at the surface of the hyphae. $\times \mathbf{9 7 0}$.

Fig. 10. Wet mount alizarin red stain of cluster of clubs from a crushed granule showing the heavy calcification of the clubs. $\times \mathbf{9 7 0}$.

Plate 5. Effect of chemical treatment on the cells and clubs of Actinomyces bovis

Fig. 11. Crushed preparation of a 'sulphur granule' after extraction with cold trichloroacetic acid, aqueous ethanol, hot trichloroacetic acid of Park \& Hancock (1960) and after treatment with trypsin, ribonuclease, and pepsin according to the procedure of Cummins \& Harris (1956). Note the difference in sizes of the two clubs in the preparation and the suggestion of the hypha within the larger club. Water mount, medium dark phase contrast. $\times 1870$.

Fig. 12. Club from a granule treated as in fig. 13, but with additional extractions using $88 \%$ phenol $(\mathrm{w} / \mathrm{v})$ and hot $10 \%(\mathrm{w} / \mathrm{v}) \mathrm{KOH}$. Note the internal hypha, now apparent with the light microscope. Water mount. $\times 2900$.

Fig. 13. Same club as in fig. 12 but photographed with medium dark phase contrast, water mount. $\times 2900$.

Plate 6. Effect of $5 \%(w / v)$ trichloroacetic acid extraction on the 'sulphur granules' of Actinomyces bovis as observed with the electron microscope

Fig. 14. Ultrathin section of the granule showing deposit of calcium phosphate on the surface of the cells, within the cells, and saturating the cementing substance. $\times 11,000$.

Fig. 15. Section of a granule after extraction with trichloroacetic acid. Note complete absence of electron dense material and relative high concentration of cementing material containing abnormal cells. $\times 13,800$.

Fig. 16. Cross-section of clubs from a trichloroacetic acid extracted granule showing the relative size of the capsule and normal hyphae with it. $\times 9100$. 